\title{
THE MINERAL WEALTH OF THE CIRCUM-ARCTIC BELT
}

\author{
Volkov A. V., Galyamov A. L., Lobanov K. V. \\ Institute of Geology of Ore Deposits, Petrography, Mineralogy and Geochemistry, RAS (Moscow, Russian Federation)
}

\section{The article was received on October 30, 2018}

\begin{abstract}
On the basis of spatial and statistical GIS analysis the article assesses the prospects for the development of strategic metals resources in the Circum-Arctic Belt (CAB). Despite the centuries-old history of mining operations, the CAB mineral wealth contains still sufficient mineral raw resources. However, $\mathrm{Ni}, \mathrm{Cu}, \mathrm{MG}, \mathrm{Di}, \mathrm{P} 2 \mathrm{O}$, $\mathrm{Zn}$, $\mathrm{Pb}, \mathrm{Au}, \mathrm{Ag}, \mathrm{Fe}-$ ores, Ti, etc. are currently of the greatest importance for the mining industry in the CAB. The obtained results are based on the most complete database compiled for deposits of various mineral types of the Russian and foreign Arctic.

The analysis showed that the current state of the mineral resource base of the CAB is quite satisfactory and ensures sustainable development of the countries' economies within it. The same assessment can be made for individual $C A B$ sectors. The mining industry, despite environmental problems, has significant development prospects in almost all CAB sectors and in particular, in the Arctic zone of Russia.
\end{abstract}

Keywords: Arctic, the Circum-Arctic Belt, mineral wealth, metallogeny, deposit, strategic metals, fosfates, diamonds, prospects of the Arctic zone of Russia.

This research is financially supported by the RFFI — Russian Fund of Fedral Property (grant № 18-05-70001) "Study of the geological and geodynamic settings of the formation of large deposits of strategic metals in the Arctic zone of Russia: conclusions for forecasting and searching for new deposits."

\section{Information about the authors}

Volkov Alexander Vladimirovich, Doctor of Geological and Mineralogical Sciences, Head of Laboratory, Institute of Geology of Ore Deposits, Petrography, Mineralogy and Geochemistry, RAS (35, Staromonetny per., Moscow, 119017, Russia), e-mail: tma2105@mail.ru.

Galyamov Andrey Lvovich, Ph.D., Senior researcher, Institute of Geology of Ore Deposits, Petrography, Mineralogy and Geochemistry, RAS (35, Staromonetny per., Moscow, 119017, Russia), e-mail: alg@igem.ru.

Lobanov Konstantin Valentinovich, Doctor of Geological and Mineralogical Sciences, Corresponding Member of RAS, Chief Researcher, Institute of Geology of Ore Deposits, Petrography, Mineralogy and Geochemistry, RAS (35, Staromonetny per., Moscow, 119017, Russia), e-mail: lobanov@igem.ru.

\section{Bibliographic description}

Volkov A. V., Galyamov A. L., Lobanov K. V. The mineral wealth of the Circum-Arctic Belt. Arctic: Ecology and Economy, 2019, no. 1 (33), pp. 106-117. DOI: 10.25283/2223-4594-2019-1-106-117. (In Russian). 


\title{
МИНЕРАЛЬНОЕ БОГАТСТВО ЦИРКУМАРКТИЧЕСКОГО ПОЯСА
}

\author{
А. В. Волков, А. Л. Галямов, К. В. Лобанов \\ ФГБУН Институт геологии рудных месторождений, петрографии, минералогии и геохимии РАН \\ (Москва, Российская Федерация)
}

Статья поступила в редакцию 30 октября 2018 г.

На основе пространственно-статистического ГИС-анализа в статье оценены перспективы развития добычи стратегических минеральных ресурсов в Циркумарктическом поясе (ЦАП). Несмотря на вековую историю горнодобывающих работ, недра ЦАП содержат еще достаточное количество минерального сырья. Однако наибольшее значение для горнодобывающей промышленности в ЦАП в настоящее время имеют Ni, Cu, металлы платиновой группы, $\mathrm{Di}^{1}, \mathrm{P}_{2} \mathrm{O}_{5}, \mathrm{Zn}, \mathrm{Pb}, \mathrm{Au}, \mathrm{Ag}$, Fe-руды, Ti и др. Полученные результаты основаны на анализе наиболее полной базы данных, составленной по месторождениям различных минеральных типов российской и зарубежной Арктики. Выполненный анализ показал, что современное состояние минерально-сырьевой базы ЦАП вполне удовлетворительно и обеспечивает устойчивое развитие экономики стран в его пределах. Такую же оценку можно дать и по отдельным секторам ЦАП. Горнодобывающая промышленность, несмотря на экологические проблемы, имеет значительные перспективы развития практически во всех секторах ЦАП и в частности на территории Арктической зоны Pоссии.

Ключевые слова: Арктика, Циркумарктический пояс, минеральное богатство, металлогения, месторождение, стратегические металлы, фосфаты, алмазы, перспективы Арктической зоны России.

\section{Введение}

Циркумарктический пояс (ЦАП) огромным кольцом охватывает окраины континентов и многочисленные острова вокруг Северного Ледовитого океана. Недра ЦАП богаты не только цветными и благородными, но и черными, редкими и редкоземельными металлами, а также алмазами и углем (рис. 1).

В последнее десятилетие геополитические интересы России последовательно перемещаются на Север, в Арктику. Правительство планирует в ближайшей перспективе создать здесь мощный минерально-сырьевой комплекс на основе развития Северного морского пути [1]. Россия занимает первое место в мире среди арктических стран - производителей минерального сырья. При этом детальные металлогенические исследования выполнены лишь для отдельных регионов российской Арктики, значительная часть которой (более 4 млн км²) остается слабо изученной в силу труднодоступности.

С начала XXI в. из недр ЦАП добывается огромное количество разнообразных полезных ископаемых, главные из которых - $\mathrm{Cu}, \mathrm{Au}, \mathrm{Ag}, \mathrm{Pb}, \mathrm{Zn}, \mathrm{Ni}, \mathrm{Ti}, \mathrm{Cr}$, металлы платиновой группы (MPG), Со, редкоземельные металлы (РЗМ), алмазы, фосфатное сырье, железные руды, уголь и др. Пояс знаменит мирового класса $\mathrm{Ni}$-Cu-MPG месторождениями (Норильская 


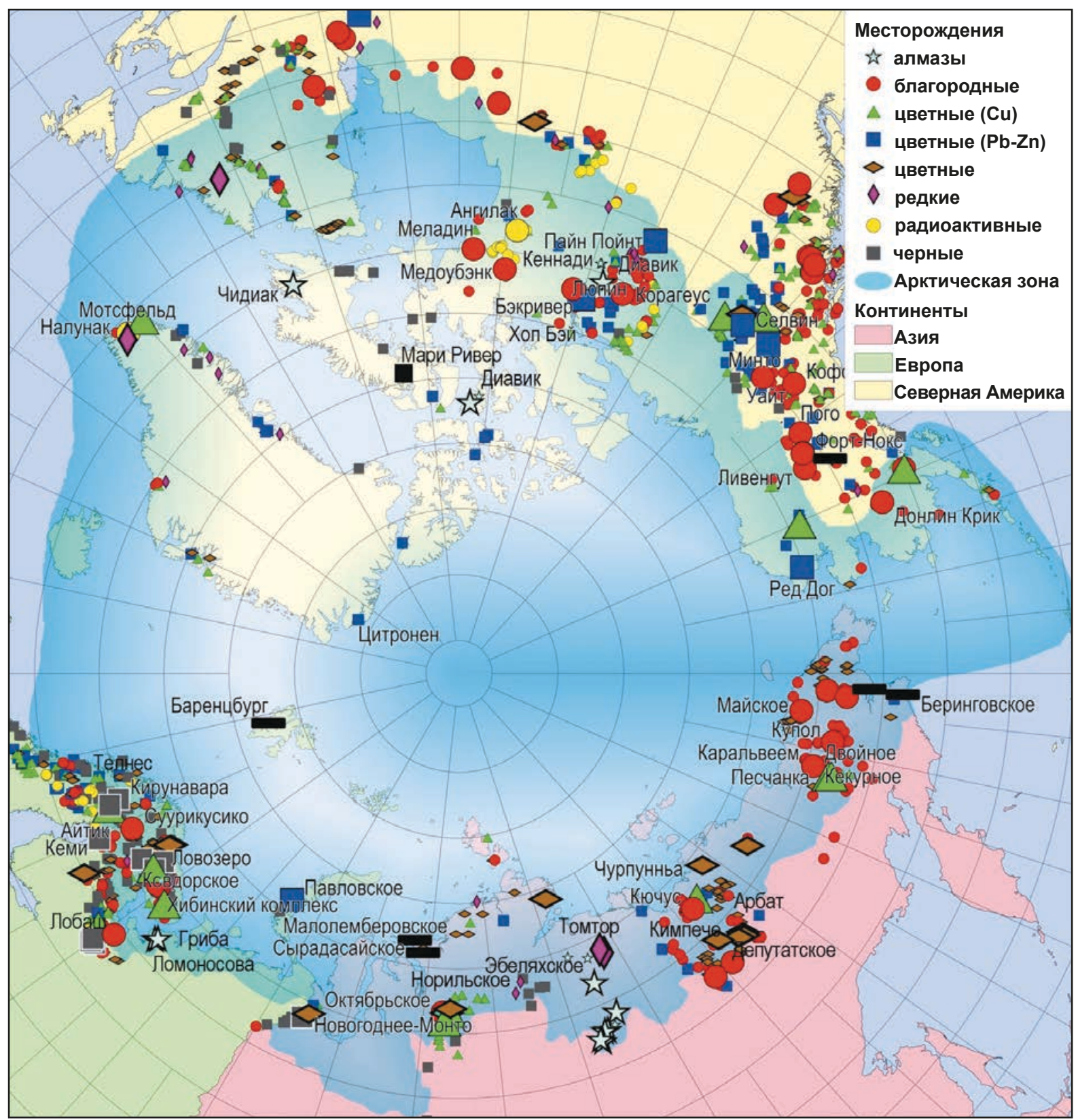

Рис. 1. Распространение месторождений твердых полезных ископаемых в ЦАП (по данным ГИС-анализа) Fig. 1. Distribution of solid mineral deposits in Circum-Artic Belt - CAB (according to GIS analysis)

группа, Печенгская группа и др.), Pb-Zn-Ag стратиформными месторождениями (Ред Дог, Павловское, Селвин и др.), месторождениями алмазов (Ломоносовское, Гриба, Диавик и др.). Мировую известность получили также апатитовые месторождения Хибин, $\mathrm{Au}-\mathrm{Ag}$ эпитермальные месторождения Чукотки (Kyпол, Двойное), месторождения титана Телнес в Норвегии, железных руд района Кируна на севере Швеции, месторождения Аu, связанные с интрузивами гранитоидов (Форт Нокс, Пого, Ливенгуд) Аляски, медно-порфировые (Пебл, Айтик, Песчанка), золото-сульфидные вкрапленных руд (Майское, Донлин Крик, Кючус) и др. (см. рис. 1).
Циркумарктический пояс — одна из важнейших глобальных металлогенических структур, формировавшаяся на протяжении всей истории Земли, с архея по кайнозой. Протяженность внешней границы ЦАП свыше 12 тыс. км, а ширина варьирует от нескольких сотен до тысяч километров. В ЦАП традиционно выделяются следующие национальные сектора: России, США, Канады, Дании (Гренландия), Исландии, Норвегии.

Цель статьи - показать, что горнодобывающая промышленность, несмотря на экологические проблемы, имеет значительные перспективы развития в ЦАП, в частности на территории Арктической зоны 


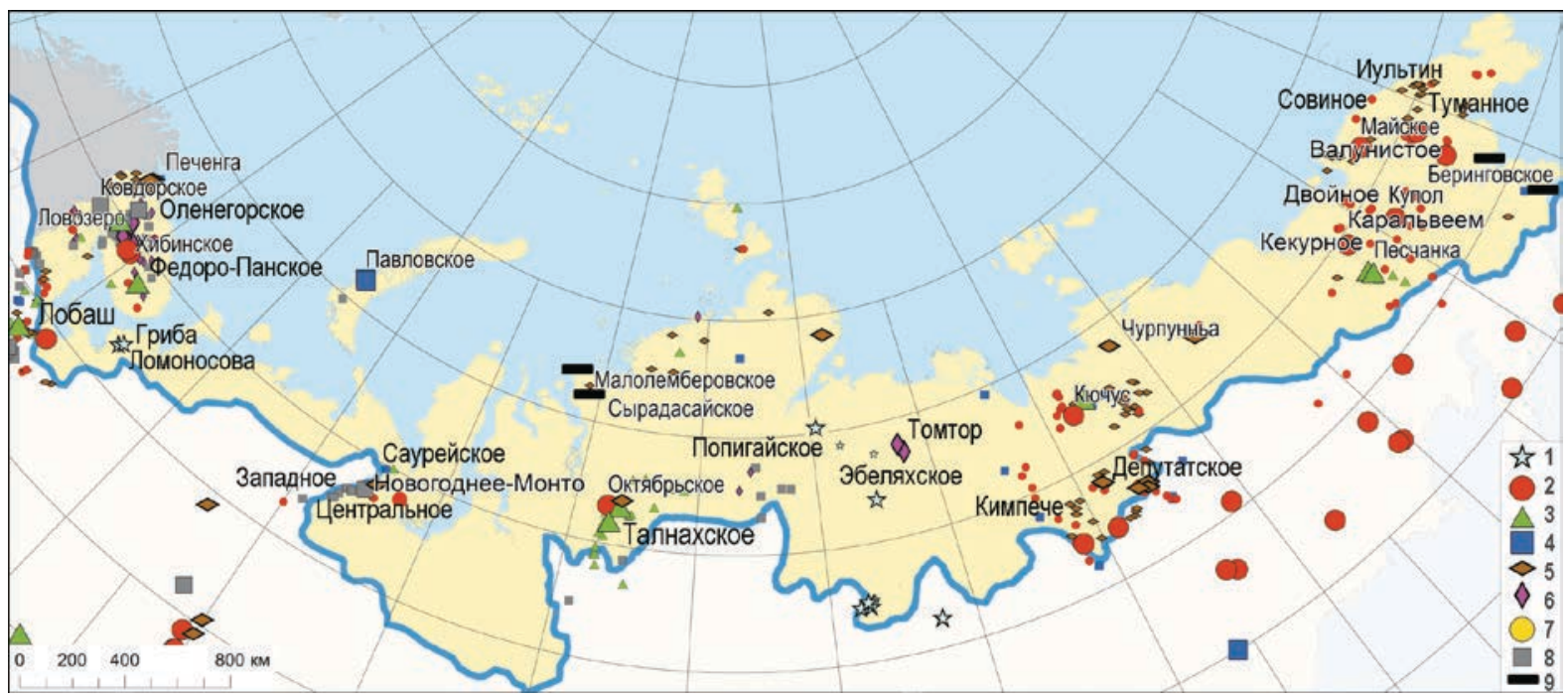

Рис. 2. Размещение месторождений твердых полезных ископаемых в российском секторе ЦАП (по данным ГИС-анализа): 1-9 месторождения твердых полезных ископаемых: 1 - алмазов, 2 - благородных металлов (Pt, Pd, Au, Ag), 3-5 - цветных металлов: 3 - Сu-Mo, 4 - Zn-Pb, 5 - Sn-W, 6 - редких металлов (Р3M, Nb, Тa и др.), 7 - урана, 8 - черных металлов (железных и хромовых руд), 9 - угля

Fig. 2. Location of solid mineral deposits in the Russian sector of CAB (according to GIS analysis): 1-9 - mineral deposits: 1 diamonds, 2 - precious metals (Pt, Pd, Au, Ag), 3-5 - nonferrous metals: 3 - Cu-Mo, 4 - Zn-Pb, 5 - Sn-W, 6 - rare metals (REE, Nb, $\mathrm{Ta}$, Sc etc.), 7 - uranium, 8 - ferrous metals (Fe and $\mathrm{Cr}$ ores), 9 - coal

Российской Федерации (АЗРФ) ${ }^{1}$ (рис. 2). В ходе подготовки материала изучены многочисленные отечественные и зарубежные публикации, а также данные сайтов геологических служб, Министерства природных ресурсов, горнодобывающих и геологоразведочных компаний. Подготовлен ГИС-проект, включающий картографический материал и базу данных по отечественным и зарубежным месторождениям ЦАП.

Публикация продолжает серию статей Института геологии рудных месторождений, петрографии, минералогии и геохимии РАН, посвященных минеральным ресурсам Арктики.

\section{Минерально-сырьевой сектор Циркумарктического пояса}

База данных по Арктике включает информацию о размещении более 26 тыс. объектов - рудных и россыпных месторождений, рудопроявлений, точек минерализации, в том числе в России - более 8 тыс. Среди объектов благородных металлов насчитывается около 400 месторождений, среди них 33 крупных. В число медных объектов (около 4 тыс.) входит более 350 месторождений, из них 7 крупных; более тысячи свинцово-цинковых проявлений, включая более 200 месторождений, в том числе 9 крупных. В состав остальных объектов цветных металлов (более 3 тыс.) входит около 300 месторождений (6 крупных). Группа черных металлов в базе представлена более

\footnotetext{
${ }^{1}$ Арктическая зона Российской Федерации сформирована в соответствии с указами Президента РФ № 296 от 2 мая 2014 г. и № 287 от 27 июня 2017 г.
}

чем 1000 объектов, среди которых более 200 месторождений, включая 9 крупных. Среди проявлений (около 450) редких металлов к месторождениям относятся 74 объекта, из них 3 крупных. Объектов радиоактивных металлов насчитывается более 500, включая 47 месторождений. База данных через координатную систему связана с бесшовной цифровой геологической картой, масштаб которой варьирует от 1:2 500000 до 1:50 000 в зависимости от тематики включенных в базу данных слоев.

Несмотря на вековую историю горнодобывающих работ, недра ЦАП содержат еще достаточное количество твердых полезных ископаемых (ТПИ). Однако наибольшее значение для горнодобывающей промышленности в ЦАП в настоящее время имеют MPG, $\mathrm{Di}, \mathrm{Ni}, \mathrm{Co}, \mathrm{Zn}, \mathrm{Ti}, \mathrm{P}_{2} \mathrm{O}_{5}, \mathrm{Ag}, \mathrm{Pb}, \mathrm{Fe-руда,} \mathrm{Au,} \mathrm{Cu} \mathrm{и} \mathrm{др.}$ (рис. 3).

Для сравнительного анализа по секторам ЦАП количество добытых ТПИ оценено в долларах (по среднегодовым ценам на 2017 г. [2; 3]). Такой же сравнительный анализ выполнен и по субъектам АЗРФ. Кроме того, результаты по ЦАП сопоставлялись с данными по миру в целом (см. рис. 3), а результаты по российскому сектору - с данными по ЦАП (рис. 4) и стране в целом. Доля арктического минерального сырья в мировых запасах и добыче вычислялась на основе данных [2]. Доля арктического минерального сырья в запасах и добыче России определена с учетом данных [3].

Минеральное богатство достаточно равномерно распределено по основным секторам ЦАП (рис. 5). Российский сектор занимает лидирующую позицию по суммарной добыче минерального сырья, на вто- 


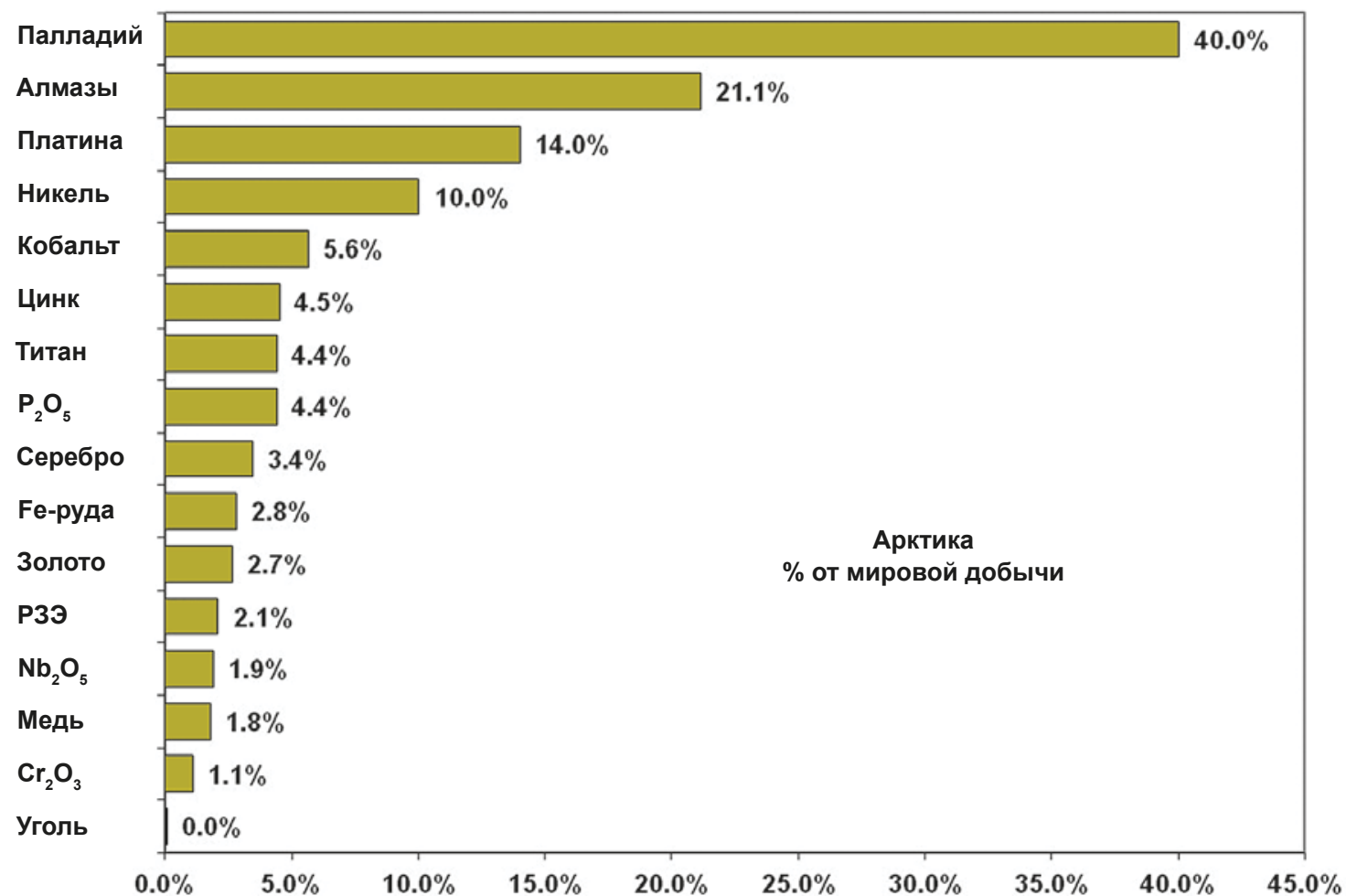

Рис. 3. Добыча ТПИ в ЦАП в 2017 г., \% от мировой добычи

Fig. 3. Mining of solid minerals in CAB in 2017 , \% of world production

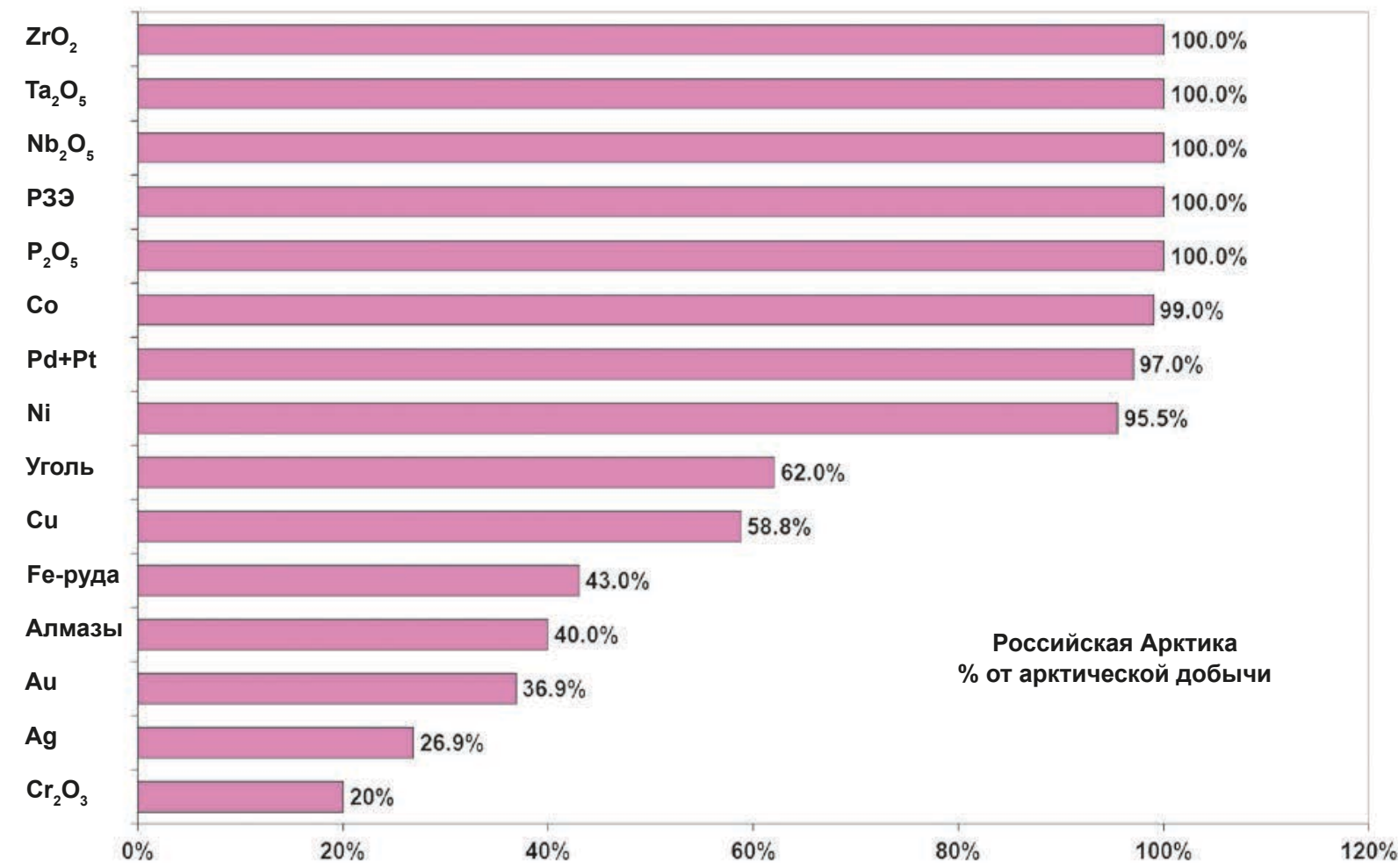

Рис. 4. Добыча ТПИ в российском секторе в 2017 г., \% от добычи ЦАП

Fig. 4. Mining of solid minerals in the Russian arctic sector in $2017, \%$ of CAB production 


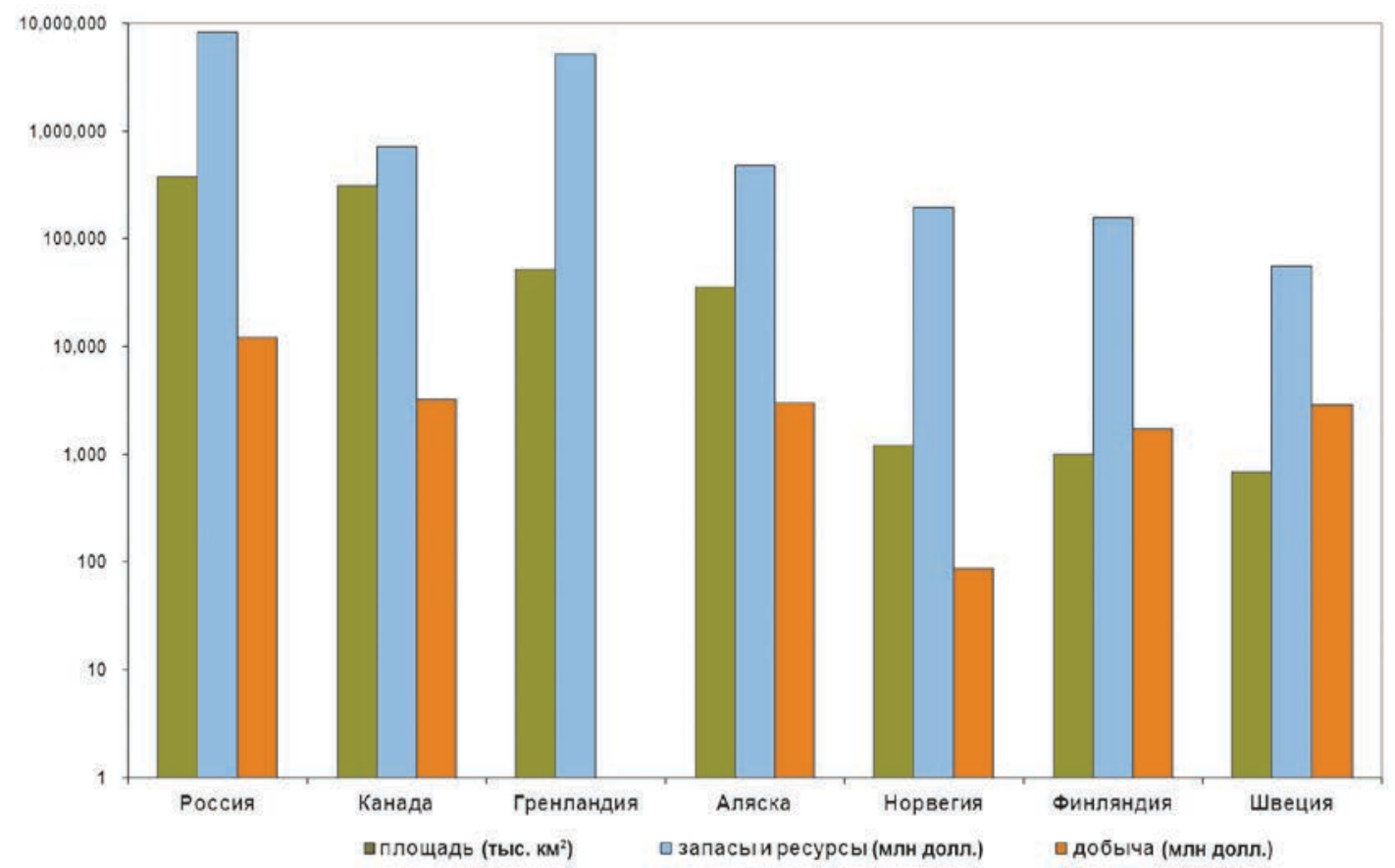

Рис. 5. Добыча, запасы ТПИ (2017 г.) и площади национальных секторов в ЦАП

Fig. 5. Mining, reserves of solid minerals (2017) and areas $\left(\mathrm{tkm}^{2}\right)$ of national sectors in the CAB

ром месте Канада, на третьем с небольшим отставанием США. Среди российских регионов по стоимости добываемого сырья лидирует Таймырский АО (ПАО «Норникель»), на втором месте Мурманская область (ПАО «Норникель», ПАО «Фосагро» и ПАО «Северсталь») на третьем Чукотский АО (Кинросс Голд, ОАО «Полиметалл») (рис. 6).

Судя по рис. 5, минерально-сырьевой сектор ЦАП обладает большими перспективами развития (в 1,52 раза). Наибольший потенциал роста добычи ТПИ можно прогнозировать на практически не освоенной территории Гренландии. Высоки перспективы открытия новых крупных месторождений в арктических секторах России, США и Канады. В старопромышленных регионах скандинавских стран стагнация добычи минерального сырья скорее всего продолжится в ближайшей и среднесрочной перспективе.

Судя по рис. 6, российский минерально-сырьевой сектор в ЦАП обладает большими перспективами развития. Наибольший потенциал роста добычи ТПИ можно прогнозировать на практически не освоенной территории северных улусов Якутии, Таймыре, Чукотке, в Архангельской области и Республике Карелия.

Ниже приведены результаты сопоставления в пределах национальных секторов ЦАП добычи основных видов ТПИ и активных запасов, разрабатываемых и подготавливаемых к освоению месторождений.

\section{Черные металлы}

Железные руды. Доля ЦАП в производстве железных руд не превышает 2,8\% мировой добычи (см. рис. 3). По добыче Fе-руд на первом месте в ЦАП на- ходится Мурманская область (Россия), где разрабатываются семь месторождений железистых кварцитов и комплексное апатит-магнетитовое месторождение Ковдор, на втором месте - северная Швеция (район Кирунавара), на третьем - месторождение железистых кварцитов Мари Ривер (Нунавут, Канада). Доля России в суммарной добыче ЦАП - 43\% (31,2 млн т [3]). Подземная эксплуатация в районе Кирунавара сосредоточена на 10 рудниках, которые в настоящее время производят 28,1 млн т железо-апатитовой руды в год [2] (39\% от ЦАП). Железо-оксид-апатитовое месторождение Малмбергет - одно из крупнейших в мире с оцененными в 2015 г. запасами руды в 346 млн т с 42,5\% Fe [4]. Перспективы развития добычи железных руд в ЦАП связаны с Гренландией [5]. Несколько крупных железорудных районов, приуроченных к докембрийским зеленокаменным и орогенным поясам, вытягиваются своеобразной цепочкой вдоль западного и северо-западного побережья острова, где в железистых кварцитах (BIF) отмечаются массивные линзы и слои окисного железа. Добыча железных руд на месторождении Мари Ривер по плану компании при выходе проекта на полную мощность достигнет 10 млн т.

Хромовые руды. Добыча хромовых руд в ЦАП ведется на месторождениях Кеми (северная Финляндия) [6] и Центральное в Ямало-Ненецком автономном округе (ЯНАО) [3]. Месторождение Кеми представлено стратиформными телами хромитов в расслоенной базит-ультрабазитовой интрузии [6]. В январе 2015 г. запасы руды, по данным компании, 


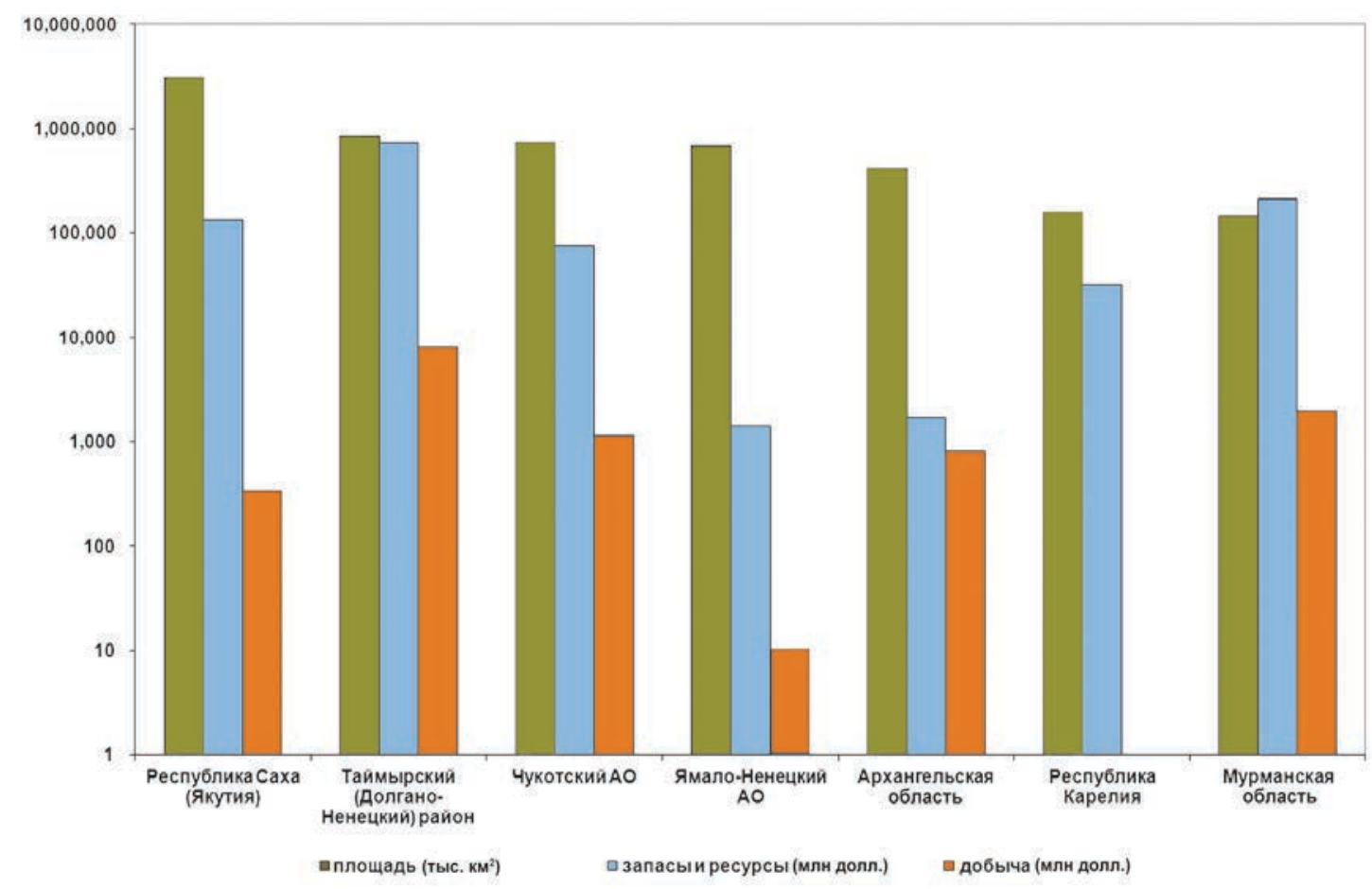

Рис. 6. Добыча, запасы ТПИ (2017 г.) и площади субъектов России в Арктической зоне

Fig. 6. Mining, reserves of solid minerals (2017) and areas (tkm2) of the Russia subjects in the Arctic zone

составляли 48 млн т с содержанием 25,9\% $\mathrm{Cr}_{2} \mathrm{O}_{3}$, а минеральные ресурсы, в основном предполагаемые, - 100 млн т при 29,4\% $\mathrm{Cr}_{2} \mathrm{O}_{3}$. В 2017 г. в Кеми было добыто 2,4 млн т руды, а обогатительная фабрика извлекла 400 тыс. т кусковых (36\% $\left.\mathrm{Cr}_{2} \mathrm{O}_{3}\right)$ и 850 тыс. т металлургических $\left(45 \% \mathrm{Cr}_{2} \mathrm{O}_{3}\right)$ концентратов. Месторождения и рудопроявления хромитов ЯНАО приурочены к альпинотипным гипербазитовым массивам полярного Урала. В пределах массива Рай-Из разведаны два месторождения, на долю которых в совокупности приходится 12,3\% запасов хромовых руд страны [3]: Центральное - 3,5 млн т со средним содержанием $37,73 \% \mathrm{Cr}_{2} \mathrm{O}_{3}$ и Западное - 2,9 млн т с 39,07\% $\mathrm{Cr}_{2} \mathrm{O}_{3}$. Прогнозные ресурсы хромитов в ЯНАО составляют $21 \%$ российских 24,4 млн т в массиве Рай-Из (в недрах Центрального месторождения - 13 млн т, Западного - 1,9 млн т) и Войкаро-Сыньинском месторождении (5,2 млн т). В 2016 г. на месторождении Центральное добыто 299 тыс. т хромовой руды, или почти две трети российской добычи [3]. В Мурманской области расположено Сопчеозерское месторождение, содержащее 9,5 млн т хромовых руд (почти 19\% запасов страны) со средним содержанием $\mathrm{Cr}_{2} \mathrm{O}_{3} 25,7 \%$. Также на территории области выявлено два хромитовых рудопроявления, прогнозные ресурсы категории $\mathrm{P}_{1}$ которых в сумме составляют 11,9 млн т [3]. Анортозитовый комплекс Фискенессет на западе Гренландии вмещает многочисленные хромитовые тела [5]. Интрузивные тела комплекса, простирающиеся полосой более чем на 200 км при средней ширине 400 м, насчитывают суммарные ресурсы около 100 млн т низкокачественной хромовой руды. Современные и экономически эффективные технологические решения по обогащению убогих высокожелезистых хромовых руд отмеченных выше объектов позволит по примеру Финляндии вовлечь их в освоение.

\section{Цветные металлы}

Никель. Доля арктического никеля составляет 10\% производства в мире (см. рис. 3). За пять лет производство никеля в Арктике снизилось на 4,5\% [4]. Добычу никеля в Арктике ведет главным образом Россия и в небольшом количестве - Финляндия. Доля российского никеля составляет в арктических запасах и добыче 95,5\%. В то же время доля арктического никеля в запасах и добыче России составляет 70,5\% и 83,3\% соответственно [3]. ПАО «Норникель» эксплуатирует три месторождения на севере Красноярского края (Заполярный филиал) и четыре месторождения в Печенгском рудном районе (ОАО «Кольская ГМК»). В 2017 г. «Норникель» обеспечил почти 93\% добычи никеля в стране (217 тыс. т), на 8\% меньше относительно предыдущего года, что связано с реконструкцией производства [3]. Потенциальными ресурсами никеля обладает Гренландия, где сульфидно-никелевая минерализация залегает в основных и ультраосновных породах в центральной части Западной Гренландии [5].

Кобальт. Российское производство Со в Арктике (ПАО «Норникель») - 5,6\% мирового производства, активные запасы - 3,3\% мировых запасов [2]. Ко- 
бальт извлекается попутно при основном производстве меди и никеля. Доля российского Со составляет в арктических запасах и добыче 99\%.

Титан. Арктика (Норвегия) производит около 4,4\% мирового титана (см. рис. 3). Норвегия по запасам титановых руд (4,8\%) занимает одно из ведущих мест в мире [2]. Доля российских титановых руд составляет 42\% общих арктических запасов. В то же время доля арктических руд в запасах титана России - около 9\% [3]. В Норвегии основной промышленный интерес представляет анортозитовая провинция Эйгерсунн, где известно крупнейшее в Европе месторождение Тельнес с общими запасами ильменита 300 млн т и активными запасами 64 млн т [4]. В 2017 г. здесь добыто 260 тыс. т ильменитового концентрата [2]. Норвежская «Nordic Mining ASA» планирует освоить уникальное рутиловое месторождение Энгебо. При мощности рудника 10 млн т/ год возможно получать ежегодно 200 тыс. т рутилового концентрата, попутно извлекая гранатовый концентрат [4].

Цинк. Общий объем добычи цинка в Арктике составляет 4,5\% мирового производства (см. рис. 3), а доля арктических руд в мировых запасах - 3,8\% [4]. Добыча в Арктике уменьшилась почти вдвое по сравнению с 2002 г. [7], что связано с ростом добычи цинка в других регионах мира. Доля российского цинка составляет в арктических запасах 13\% [4]. В то же время доля арктического цинка в запасах России невелика - 4,2\% [3]. Аляска по-прежнему извлекает почти весь арктический цинк [9]. Рудник Ред Дог один из крупнейших в мире, по качеству руд он превосходит все известные месторождения в два-три раза [8]. Однако к 2012 г. основные его запасы были отработаны, и карьер рудника перенесен на соседнее месторождение Аккалук, которого хватит до 2031 г. [10]. В России разведано всего одно месторождение Павловское (остров Новая Земля), которое по качеству руд сравнимо с зарубежными аналогами [3]. В зарубежной Арктике на стадии разведки находятся многочисленные колчеданные и стратифоромные полиметаллические месторождения: Лик в 40 км от рудника Ред Дог (Аляска) [9] и Селвин (Юкон, Канада), а также группа месторождений в районе Хакет Ривер (Нунавут, Канада) [11]. На севере Гренландии в районе фьорда Ситронен разведаны 102 млн т руды при содержании цинка $4,7 \%$ и свинца около 2\% [5].

Свинец. Развитие арктической минерально-сырьевой базы свинца во многом обусловлено планами по добыче цинка (см. выше). По сравнению с 2002 г. [7] доля арктического производства свинца (Аляска) в мире сократилась вдвое (2,37\%), как и цинка. Свинец в Арктике добывается попутно главным образом с цинком (рудники Ред Дог и Грин Крик, Аляска) и в меньшей степени с цинком и медью. Доля российского свинца составляет в арктических запасах почти 18\%. В то же время его доля в запасах России невелика $-4,3 \%$ [3].
Медь. ЦАП обеспечивает всего 2,7\% мировой добычи Cu (см. рис. 3), в основном в России и в меньшей степени в Швеции и северной Финляндии [11]. Доля ЦАП в мировых активных запасах Сu составляет около 9\% [4], лидеры - Россия и США (Аляска). Следует отметить, что с 2002 г. [7] доля арктической Си в мировой добыче сократилась почти в два раза. Доля российской Сu в арктических запасах и добыче составляет 50,1\% и 58,8\% (387,64 тыс. т в 2017 г. [3]) соответственно (см. рис. 4). Доля арктической $\mathrm{Cu}$ в запасах и добыче России составляет более 40\% и 54,4\%, соответственно [3]. Причем более 30\% активных запасов Си сконцентрировано в сульфидных Cu-Ni месторождениях Норильского рудного района: в Октябрьском (более $22 \%$ российских запасов меди) и Талнахском (11,6\%) [3]. В Чукотском AO запасы меди Cu-Mo-Au-порфирового месторождения Песчанка составляют 3,7 млн т, или 4\% российских запасов. Кроме того, в недрах Баимской зоны локализовано 5,95 млн т прогнозных ресурсов $\mathrm{Cu}$ категории $\mathrm{P}_{1}$ - почти половина наиболее достоверных ресурсов Сu страны [3]. Cu-Au-порфировое месторождение Айтик (район Скелет, шведская Лапландия) занимает второе место по добыче $\mathrm{Cu}$ в Арктике после Норильска (97,6 тыс. т в 2017 г. по данным «Boliden»). Здесь действует самый большой в Европе карьер. Руды содержат в среднем 0,3\% Cu, 0,1 г/т Au и 2 г/т Ag [11]. Следует отметить, что добыча Cu в ЦАП имеет значительные перспективы роста. Запасы Cu порфирового месторождения Пебл (36 млн т [9]), как и сопутствующих компонентов, в 10 раз больше, чем его российского аналога Песчанки [3]. Однако началу строительства крупнейшего в мире рудника препятствует значительный экологический риск [9].

Молибден. В Циркумарктической зоне разведано несколько крупных собственно молибденовых месторождений. Кроме того, крупные запасы молибдена подсчитаны в качестве попутного сырья на месторождениях Пеббл и Песчанка [3; 9]. Доля российского Мо составляет в арктических запасах 2,36\%, а в запасах России - 4,7\% [4]. На востоке Гренландии выявлено крупное месторождение Малмберг, ресурсы которого превышают 410 тыс. т, а среднее содержание молибдена составляет 0,15\% [5]. В Норвегии в районе Хурдал добыча молибдена планируется на месторождении Норди. Ресурсы месторождения - 210 млн т при среднем содержании молибдена 0,13\% [11]. В Таймырском АО известно Убойнинское месторождение молибдена, расположенное вблизи поселка Диксон, руды которого характеризуются высоким (до 0,15\%) содержанием молибдена [12]. В арктических районах Карелии известно крупное молибденовое месторождение Лобаш (см. рис. 2). Запасы штокверковых руд месторождения по категории $C_{1}-56,9$ тыс. т при среднем содержании молибдена 0,068\%, по категории $\mathrm{C}_{2}-$ соответственно 71,2 тыс. т и 0,059\% [13]. Геологоэкономический анализ показывает, что в настоящее 
время в мире введено в строй несколько крупных молибденовых рудников (в США, Канаде, Чили, Перу, Австралии и др.), конкурировать с которыми месторождения ЦАП не могут.

Олово. В российской Арктической зоне сосредоточена крупнейшая минерально-сырьевая база олова в мире [3; 4]. Здесь известны два уникальных оловорудно-россыпных районов: Северо-Янский (Якутия) и Пыркакайский (Чукотка). В 1990-е годы добыча олова из рудных месторождений и россыпей в этих районах превышала 15 тыс. т в год. В настоящее время добыча олова и вольфрама в них прекращена по экономическим причинам. Доля российского олова составляет в арктических запасах 100\%, а в запасах России - около 50\% [3; 4]. Перспективен на открытие новых оловорудных месторождений и полуостров Стюарт (Аляска) [11].

Вольфрам. В арктической России производство вольфрама остановлено в середине 90-х годов прошлого века, а в Канаде - в 2015 г. в связи с конъюнктурой рынка. Доля российского W составляет в арктических запасах почти 43\% [4]. В то же время его доля в запасах России невелика - 5,1\% [3]. Основные разведанные запасы коренного и россыпного вольфрама сосредоточены в Иультинском (более 50\% всех запасов), Чаунском (24,8\%), Шмидтовском и Северо-Янском районах [3]. В случае реанимации этих приисков добыча вольфрама будет возрастать пропорционально добыче олова.

\section{Благородные металлы}

В последние годы высокий уровень мировых цен на благородные металлы - основная причина развития геолого-разведочных работ и ввода в строй новых рудников в отдаленных районах Арктики (см. рис. 1). Однако независимо от широкого спектра минеральных богатств исторически именно золото остается главной целью геологических исследований в этих районах.

Золото. В современной мировой добыче Au доля ЦАП составляет $2,7 \%$ (см. рис. 3), а доля в мировых запасах - более 13,4\%. Основная добыча золота ЦАП сосредоточена в Чукотском АО (Россия) и на Аляске (США), в меньшей степени в Северной Канаде (Нунавут) и скандинавской Арктике, кроме того, небольшое производство Au существовало до 2013 г. в Гренландии [4]. Попутно Au добывается в заметных количествах из Норильской группы Cu$\mathrm{Ni-месторождений} \mathrm{и} \mathrm{Cu-Au-порфирового} \mathrm{месторож-}$ дения Айтик (4,5 и 1,7 т соответственно) [4]. Из россыпей в Арктике добывается ежегодно около 7 т Au (Аляска, Юкон, Чукотка, Якутия). Доля российского $\mathrm{Au}$ в арктической добыче в целом составляет 36,9\% (см. рис. 4). В то же время доля арктического золота в запасах и добыче России составляет 11,2\% и 9,75\% соответственно [3]. Перспективы значительного роста золотодобычи в ЦАП связаны с вводом в строй нескольких новых крупных месторождений: Донлин Крик, Левингут и Пебл (Аляска), Песчанка
(Чукотский АО), пяти месторождений в провинции Юкон, двух в Нунавут и одного в Северо-Западных территориях (Канада) [4; 11]. В последние годы активные поиски новых месторождений золота ведутся на территории Исландии и Шпицбергена, где обнаружены перспективные рудопроявления [11]. Таймыр - новый потенциально крупный золотоносный регион в российской Арктике. Общие ресурсы золота оцениваются в 2000 т [4; 11]. Несколько потенциальных золоторудных районов оконтурены на острове Большевик и северном Таймыре, которые также включают значительное количество россыпей [4]. Несомненный интерес как вторичный источник золота для формирования россыпей представляют золотоносные конгломераты на полуострове Челюскин (Таймыр), в Северной Карелии, Ветреном поясе (Архангельская область), а также в северной Якутии. Золотоносный потенциал арктического шельфа России сопоставим с крупными золотоносными районами страны [4]. Основной объем запасов (более 85\%) и ресурсов (не менее 70\%) в пределах шельфовой области сосредоточено на островах и вблизи береговой линии.

Платина, палладий. Одна арктическая Россия производит 40\% мирового палладия и 14\% мировой платины (см. рис. 3). Незначительное количество МПГ добывается в северной Финляндии [4]. Доля российских МПГ в арктической добыче составляет 97\% (см. рис. 4), в запасах - 98\% [2; 3]. В то же время доля арктических МПГ в запасах и добыче России составляет 94,6\% и 95,4\% соответственно [3]. В российской арктической зоне сравнительно недавно были открыты крупные малосульфидные месторождения МПГ: Масловское, Верхнеталнахское, Норильское, Черногорское и Имангдинское в Норильском районе, Федорово-Панское и Мончегорское на Кольском полуострове [3]. Минерализация золото-медно-палладиевого типа установлена в лавовых потоках доллеритов острова Александра земли Франца Иосифа [14]. На севере Финляндии ресурсы группы месторождений Суханко составили 528 т МПГ (Pd/Pt = 4/1) [11]. Шведская компания «Boliden $A B$ » с 2016 г. разрабатывает в этом же районе малосульфидное месторождении Кевитса с запасами МПГ 65 т и ресурсами 129 т [4]. В 2017 г. добыто 2 т МПГ [15]. Обеспеченность запасами более 20 лет.

Серебро. Арктика извлекает около 3,4\% глобального количества серебра (см. рис. 3), доля в мировых запасах - около 4\%. Примерно 70\% производства приходится на Аляску, 26,9\% - на российскую Арктику (см. рис. 4), оставшаяся часть принадлежит Скандинавии. Доля арктического серебра в запасах и добыче России составляет 11,16\% и 13\% соответственно [3]. Все арктическое серебро производится попутно из полиметаллических и золото-серебряных руд. Перспективы развития добычи серебра связаны с освоением полиметаллических месторождений района Хакет Ривер (Нунавут, Канада). Вул- 
каногенные массивные сульфидные (VMS) руды возрастом 2,67 млрд лет более обогащены серебром (до 3000 г/т) по сравнению с другими подобными месторождениями аналогичного возраста [16].

\section{Радиоактивные, редкие}

и редкоземельные металлы

Уран. В ЦАП уран не добывается, хотя выявлено большое количество месторождений и рудопроявлений. Наиболее перспективно в плане добычи месторождение района Кигавик, расположенное в бассейне Телона северо-восточнее провинции Атабаска (Нунавут, Канада) [11]. Его запасы составляют более 50 тыс. т, а среднее содержание урана - 0,47\%. В арктической зоне Гренландии известен крупнейший ураноносный район, связанный с многофазным щелочным интрузивным комплексом Илимаусак, общие ресурсы которого оцениваются в 600 тыс. т $\mathrm{U}_{3} \mathrm{O}_{8}$ [5]. В пределах Арктической зоны России наиболее перспективна на открытие урана территория слабо изученного Анабарского щита [4].

Ниобий и тантал. Глобальный рост производства стали определяет спрос на $\mathrm{Nb}$, а развитие электронной промышленности - на Та (потребляет более 50\%). Другое основное применение Та - суперсплавы (в пределах 20\%). Добыча Nb и Та с последующим извлечением осуществляется в ЦАП только из комплексных лопаритовых руд Ловозерского месторождения, которое содержит 30\% и 26\% балансовых запасов этих металлов в России [3]. Ожидаемый в перспективе высокий уровень спроса на эти металлы со стороны российской промышленности планируется удовлетворить за счет ввода в строй Томторского рудника [3] (см. рис. 2). Однако геолого-экономические расчеты показывают, что конкурировать с бразильскими месторождениями Томтор может только на условиях преференций, предоставленных государством. В Южной Гренландии в районе Гардар открыто месторождение Мотзфельд, которое считается одним из крупнейших месторождений тантала в мире. По результатам оценки оно представлено низкосортными пирохлоровыми рудами в количестве 600 млн т [5].

Редкоземельные металлы. Комплексное Ловозерское месторождение - единственное в Росси и ЦАП, из руд которого извлекают РЗМ (около 7 тыс. т концентрата в год) [3]. Разведанные запасы Р3М Ловозерского месторождения, представленные в основном металлами цериевой группы, составляют более $25 \%$ российских, среднее содержание суммы оксидов редких земель в рудах - 1,12\%. Годовое производство не превышает 2500 т $\sum \mathrm{TR}_{2} \mathrm{O}_{3}$. В последние годы поставки на рынок России выросли в 2,2 раза [3]. В рудах нефелин-апатитовых месторождений Хибинской группы содержится более 40\% российских запасов Р3М, которые из получаемого апатитового концентрата не извлекаются [3]. В мире эта группа уникальных месторождений не имеет аналогов. Другое уникальное Томторское месторождение находится в арктической зоне Якутии. В его пределах разведан только участок Буранный, запасы которого составляют 0,7\% российских. Основные компоненты руд - Nb, P3M и Sc. Руды отличаются очень высоким содержанием Р3М $7,98 \% \sum_{\mathrm{TR}_{2} \mathrm{O}_{3}}$ [3]. Добыча руды на месторождении по плану Госкорпорации «Ростех» должна начаться в 2020 г. Месторождение (Куннесюит) в районе Гардар в Гренландии - одно из крупнейших в мире по запасам U и Р3М [5]. Здесь в последние годы выявлены и разведаны еще два месторождения Килават и Аланкуат. В 2015 г. компания «Greenland Minerals» анонсировала новые суммарные ресурсы по трем месторождениям: 1010 млн т руды содержат 270 тыс. т $\mathrm{U}_{3} \mathrm{O}_{8}$ и 11,13 млн т $\sum \mathrm{TR}_{2} \mathrm{O}_{3}$ [5].

\section{Алмазы}

В ЦАП извлекается около 21,1\% глобальной добычи алмазов (см. рис. 3), доля в мировых запасах примерно 30\%. Более 60\% производства приходится на Канаду, а 40\% - на российскую Арктику (см. рис. 4). Отметим паритет по запасам алмазов в Канадском и российском секторах ЦАП [3; 11]. В Канаде добыча алмазов сосредоточена на трех рудниках - Экати, Диавик и Гачо Kaе (см. рис. 1): в 2016 г. добыто 7,5, 7,5 и 4,5 млн карат соответственно, запасы - 124, 42,5 и 55,5 млн карат соответственно. Кроме того, ведется подготовка к освоению еще двух алмазоносных трубок - Кеннеди Норф и Чидлиак, предполагаемые ресурсы которых оцениваются суммарно в 40 млн карат. В российском секторе ЦАП алмазы добываются в Архангельской области и на севере Республики Саха (Якутия). Архангельская алмазоносная провинция - это 21,4\% общероссийских запасов алмазов, второе место после Республики Саха (Якутия) [3]. На 1 января 2017 г. доказанные запасы алмазов $\left(\mathrm{B}+\mathrm{C}_{1}+\mathrm{C}_{2}\right)$ месторождений Архангельской области составляют 248,3млн карат. В 2017 г. в результате успешной работы горно-обогатительных комбинатов они уменьшились на 7,5 млн карат - 15\% общероссийского объема добычи алмазов. Добычу россыпных алмазов в Анабарском улусе Якутии ведет АО «Алмазы Анабара» на двух приисках - Маят и Молодо. В 2016 г., по данным компании, добыто 5,1 млн карат (331,9 млн долл). Согласно стратегии развития компании до 2026 г. ежегодная добыча запланирована на уровне 4,6-4,7 млн карат, а общий объем добычи алмазов - 56,3 млн карат. Перспективы развития арктической алмазодобычи в России связываются с освоением гигантских запасов технических импактных алмазов Попигайского метеоритного кратера на северо-востоке Красноярского края [3].

\section{Фосфаты}

Доля арктического сектора России в мировом производстве фосфорного (апатитового) концентрата составляет всего 4,4\% (см. рис. 3), а качество ее продукции очень высоко. Российские ми- 
неральные удобрения - одна из главных отраслей российской химической индустрии с годовым оборотом более 10 млрд долл. По данным [3], более 70\% запасов фосфатов сосредоточено в пределах Хибино-Ловозерской минерагенической зоны Мурманской области. Суммарные запасы девяти месторождений составляют 447,5 млн т в пересчете на $\mathrm{P}_{2} \mathrm{O}_{5}$ при среднем содержании в рудах от 7,5\% до 17,24\%. В пределах группы локализованы прогнозные ресурсы в количестве 15,3 млн т. Обеспеченность запасами ОАО «Апатит», которое владеет лицензиями на освоение большей части запасов, в контурах открытой добычи составляет 1540 лет, а в контурах подземной отработки - более 100 лет. Кроме того, в Мурманской области разведаны комплексные апатит-магнетит-бадделеитовыми руды в карбонатитах Ковдорского месторождения. По данным [3], среднее содержание $\mathrm{P}_{2} \mathrm{O}_{5}$ составляет 6,6\%, запасы оцениваются в 97,6 млн т. $\mathrm{K}$ коре выветривания Ковдорского массива приурочены также апатит-штаффелитовые руды, в которых содержание $\mathrm{P}_{2} \mathrm{O}_{5}$ выше и составляет 16,8\%, однако запасы их существенно меньше и оцениваются в 6,2 млн т. Кроме того, на флангах и глубоких горизонтах месторождения прогнозные ресурсы оцениваются в 56,1 млн т [3]. В последние годы в связи с благоприятной конъюнктурой на внутреннем и внешнем рынках объем добычи фосфатов в Мурманской области возрастает.

\section{Уголь}

Добыча угля в ЦАП не превышает 2,5 млн т в год около 0,003\% мирового производства. Добыча в российском секторе ЦАП, включая Шпицберген, около 62\%, оставшаяся часть угля добывается на шахте Узебели (Аляска, США) (см. рис. 1). Доля добычи в российской Арктике составляет всего 0,03\% суммарного производства в стране [3]. Запасы и ресурсы угля в ЦАП - незначительная доля в мировых запасах (примерно 1\%). В российском секторе добыча угля сосредоточена в трех субъектах: в Чукотском AO (шахта Нагорная и разрезы Беринговского бассейна), а также в месторождениях Маломберовское (Таймыр) и Баренцбург (Шпицберген). Общие запасы Беринговского каменноугольного бассейна оцениваются более чем в 1 млрд т. К 2030 г. ежегодные объемы производства здесь могут составить 10-12 млн т высококачественного угля.

\section{Заключение}

Несмотря на вековую историю горнодобывающих работ, недра ЦАП содержат еще достаточное количество ТПИ. Наибольшее значение для горнодобывающей промышленности в ЦАП в настоящее время имеют $\mathrm{Ni}, \mathrm{Cu}, \mathrm{MPG}, \mathrm{Di}, \mathrm{P}_{2} \mathrm{O}_{5}$, Zn, Pb, Au, Ag, Fe-руды, Ті и др.

Современное состояние минерально-сырьевой базы ТПИ ЦАП вполне удовлетворительное и обеспечивает устойчивое развитие экономики стран в его пределах. Такую же оценку можно дать и по отдельным сегментам ЦАП. Горнодобывающая промышленность, несмотря на экологические проблемы, имеет значительные перспективы развития практически во всех секторах ЦАП и в частности на территории Арктической зоны России.

Несомненно, огромный потенциал еще не открытых месторождений российского сектора ЦАП заслуживает большего внимания корпорации «Росгеология» и других российских и зарубежных геологоразведочных и горнодобывающих компаний. Здесь возможно открытие нескольких новых крупных месторождений стратегических видов минерального сырья. Добыча минерального сырья в ЦАП может увеличиться в 1,5-2 раза, это позволяют имеющиеся активные запасы.

Работа выполнена при финансовой поддержке РФФИ (грант № 18-05-70001) «Изучение геологических и геодинамических обстановок формирования крупных месторождений стратегических металлов Арктической зоны России: выводы для прогнозирования и поисков новых месторождений».

\section{Литература/References}

1. Государственная программа «Социально-экономическое развитие Арктической зоны Российской Федерации на период до 2020 года». — URL: http:// static.government.ru/media/files/GGu3GTtv8bvV8gZx SEAS1R7XmzloK6ar.pdf.

Gosudarstvennaya programma "Sotsial'noekonomicheskoe razvitie Arkticheskoi zony Rossiiskoi Federatsii". [State program of the Russian Federation "Socio-economic development of the Arctic zone of the Russian Federation"]. Available at: http://static. government.ru/media/files/GGu3GTtv8bvV8gZxSEAS1 R7XmzloK6ar.pdf. (In Russian).

2. Mineral Commodity Summaries 2017. Reston, Virginia, U.S. Geological Survey, 2018, 202 p. Available at: https://doi.org/10.3133/70180197.

3. Государственный доклад «О состоянии и использовании минерально-сырьевых ресурсов Российской Федерации в 2016 и 2017 годах». - М.: ФГБУ «ВИМС», 2018. - 370 c.

Gosudarstvennyi doklad "O sostoyanii i ispol'zovanii mineral'no-syr'evykh resursov Rossiiskoi Federatsii v 2016 i 2017 godakh". [State report "On the state and use of mineral resources of the Russian Federation in 2016 and 2017"]. Moscow, FGBU "VIMS", 2018, 370 p. (In Russian).

4. Бортников Н. С., Лобанов К. В., Волков А. В. и Әр. Месторождения стратегических металлов Арктической зоны // Геология руд. месторождений. 2015. - T. 57, № 6. - C. 479-500. — DOI: 10.7868/ S0016777015060027.

Bortnikov N. S., Lobanov K. V., Volkov A. V. et al. Strategic Metal Deposits of the Arctic Zone. Geology of Ore Deposits, 2015, vol. 57, no. 6, pp. 433-453. DOI: 10.1134/S1075701515060021. 
5. Волков А. В., Галямов А. Л. Перспективы горнодобывающей промышленности Гренландии // Арктика: экология и экономика. - 2016. - № 2 (22). - С. 24-34.

Volkov A. V., Galyamov A. L. Perspektivy gornodobyvayushchei promyshlennosti Grenlandii. [Prospects for the mining industry in Greenland]. Arktika: ekologiya i ekonomika, 2016, no. 2 (22), pp. 24-34. (In Russian). 6. Metallogeny and tectonic evolution of the Northern Fennoscandian Shield: Field trip guidebook. V. Juhani Ojala, Pär Weihed, Pasi Eilu and Markku Iljina (eds.). Espoo, GTK, 2007, 98 p.

7. Lindholt L. Arctic natural resources in a global perspective. The Economy of the North. Chapter 3. Glomsrød S., Aslaksen I., eds. Oslo, Statistics Norway, 2006, pp. 27-37.

8. Сидоров А. А., Волков А. В. Освоение ресурсных регионов (на примере Аляски и Чукотского АО) // Вестн. РАН. - 2008. - № 10. - С. 867-874.

Sidorov A. A., Volkov A. V. Osvoenie resursnykh regionov (na primere Alyaski i Chukotskogo AO). [Development of resource regions (by the example of Alaska and Chukotka)]. Vestn. RAN, 2008, vol. 78, no. 10, pp. 867-874. (In Russian).

9. Athey J. E., Werdon M. B. Alaska's mineral industry 2016. Alaska Division of Geological \& Geophysical Surveys. Special Report 72, 2017, 65 p. Available at: http://doi.org/10.14509/29748.

10. Athey J. E., Freeman L. K., Harbo L. A. Alaska's Mineral Industry 2013. Alaska Division of Geological \& Geophysical Surveys. Special Report 69, 2014, 65 p. Available at: http://doi.org/10.14509/29748.

11. Mineral Resources in the Arctic. Rognvald Boyd, Terje Bjerkgård, Bobo Nordahl, Henrik Schiellerup (editors). Geological Survey of Norway, 2016, 484 p.
12. Додин Д. А., Иванов В. Л., Каминский В. Д. Российская Арктика - крупная минерально-сырьевая база страны // Литосфера. - 2008. — № 4. - С. 76-92.

Dodin D. A., Ivanov V. L., Kaminskiy V. D. Rossiyskaya Arktika - krupnaya mineral'no-syr'evaya baza strany. [The Russian Arctic - a large mineral resource base of the country]. Litosfera, 2008, no. 4, pp. 76-92. (In Russian).

13. Щипцов В. В., Иващенко В. И. Минерально-сырьевой потенциал арктических районов Республики Карелия // Тр. Карел. науч. центра РАН. - 2018. № 2. - C. 3-33. - DOI: 10.17076/део775.

Shchiptsov V. V., Ivashchenko V. I. Mineral'no-syr'evoy potentsial arkticheskikh rayonov Respubliki Kareliya. [Mineral resource potential of the Arctic regions of the Republic of Karelia]. Tr. Karel. nauch. tsentra RAN, 2018, no. 2, pp. 3-33. DOI: 10.17076/део775. (In Russian).

14. Скляров Е. В., Карякин Ю. В., Карманов Н. С. и Әр. Минералы платиноидов в долеритах о. Земля Александры (архипелаг Земля Франца-Иосифа) // Геология и геофизика. - 2016. - Т. 57, № 5. - С. 10581067. - DOI: 10.15372/GiG20160514.

Sklyarov E. V., Karyakin Y. V., Karmanov N. S et al. Platinum-group minerals in dolerites from Alexandra Land Island (Franz Josef Land Archipelago). Russian Geology and Geophysics, 2016, vol. 57, no. 5. pp. 834-841. DOI: 10.1016/j.rgg.2016.04.006.

15. Mineral Deposit Report. Kevitsa, GTK, 2018, 21 p. 16. Grant H. L. J., Layton-Matthews D., Peter J. M. Distribution and Controls on Silver Mineralization in the Hackett River Main Zone, Nunavut, Canada: An Agand Pb-enriched Archean Volcanogenic Massive Sulfide Deposit. Economic Geology, 2015, vol. 110, no. 4, pp. 943-982. DOI: 10.2113/econgeo.110.4.943.

\section{Информация об авторах}

Волков Александр Владимирович, доктор геолого-минералогических наук, заведующий лабораторией, Институт геологии рудных месторождений, петрографии, минералогии и геохимии РАН (119017, Россия, Москва, Старомонетный пер., д. 35), e-mail: tma2105@mail.ru.

Галямов Андрей Львович, кандидат геолого-минералогических наук, старший научный сотрудник, Институт геологии рудных месторождений, петрографии, минералогии и геохимии РАН (119017, Россия, Москва, Старомонетный пер., д. 35), e-mail: alg@igem.ru.

Лобанов Константин Валентинович, доктор геолого-минералогических наук, член-корреспондент РАН, главный научный сотрудник, Институт геологии рудных месторождений, петрографии, минералогии и геохимии РАН (1 19017, Россия, Москва, Старомонетный пер., д. 35), e-mail: lobanov@igem.ru.

\section{Библиографическое описание данной статьи}

Волков А. В., Галямов А. Л., Лобанов К. В. Минеральное богатство Циркумарктического пояса // Арктика: экология и экономика. — 2019. - № 1 (33). - C. 106-117. — DOI: 10.25283/2223-4594-2019-1-106-117. 